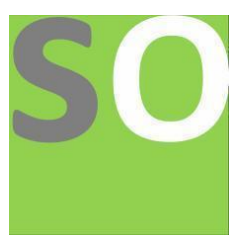

Article title: Problem Solving Performance in Physics Among Secondary School Students in Dire Dawa Ethiopia Authors: Mustefa Jibril[1]

Affiliations: Dire Dawa University, Dire Dawa, Ethiopia[1]

Orcid ids: 0000-0002-3165-2410[1]

Contact e-mail: mustefazinet1981@gmail.com

License information: This work has been published open access under Creative Commons Attribution License $\mathrm{http}: / / c r e a t i v e c o m m o n s . o r g / l i c e n s e s / b y / 4.0 /$, which permits unrestricted use, distribution, and reproduction in any medium, provided the original work is properly cited. Conditions, terms of use and publishing policy can be found at https://www.scienceopen.com/.

Preprint statement: This article is a preprint and has not been peer-reviewed, under consideration and submitted to ScienceOpen Preprints for open peer review.

DOI: 10.14293/S2199-1006.1.SOR-.PPHR66U.v1

Preprint first posted online: 04 October 2021

Keywords: Problem Solving, Performance, Physics, Private school 


\title{
Problem Solving Performance in Physics Among Secondary School Students in Dire Dawa Ethiopia
}

\author{
Mustefa JIBRIL \\ School of Electrical \& Computer Engineering, Dire Dawa Institute of Technology, Dire Dawa, Ethiopia \\ mustefa.jibril@ddu.edu.et
}

\begin{abstract}
The main aim of this study was to assess problem solving performance in physics of grade $9^{\text {th }}$ students. A test of reasoning was administered to a sample of 578 students. The results show differential performance of the students. Question based performance with background variable as school sector shows that performance of private school students was significantly better than students of public schools. Similarly female private school students performed well than male private school students.
\end{abstract}

Keywords: Problem Solving, Performance, Physics, Private school

\section{Introduction}

To solve the critical issues, and the general functions of physical education. [1] the Teachers are used to solve the problems associated with the introduction of new physics, the principles, the integration of the related physical concepts related to the application of knowledge in new situations, and the assessment of students ' understanding of the new physics knowledge. Previous studies have shown that certain factors (e.g., gender, age, prior knowledge, metacognitive skills, topics, etc), and their specific combinations can affect the students ' efficiency and competence in physics problem-solving [2-6].

A natural idea, or principle can be, or are, of course, in the absence of any of the representations, such as words, equations, symbols, charts, diagrams, or graphs. With the use of multiple representations relating to the provision of the data is in different formats, it can help physicians to explore and work with the physical system, in the same way, they can also help the students to understand the physical phenomena and their underlying principles [7-9].

Studies related to the representative of the formats and physical problems to be solved, the focus of the verbal or linguistic, pictorial, symbolic and mathematical forms [2-5, 10-12]. A few studies have investigated the effect of the different perceptions of the problem-solving strategies that are used by students, [2, 10], as well as the performance of, any opinion, failure, and learning $[4,5,12]$. Their results showed that the different presentation formats, can lead to a variety of approaches and modes of failure, as well as the additional impact on the students as they perform. For example, students tend to perform calculations, or are manipulating the symbols, rather than the quality of the strategies in order to resolve an issue with a formula, or other types of mathematical representations [2-4, 13]. The second study investigates how students relate to the physics of the problem [14], and the like, and the application or understanding of the relevant knowledge (e.g., mathematics) to solve physics problems [13,14]. These studies have identified the possible causes and the mechanisms that underlie the differences in the results of the strategy, or the difficulties of the students. 
This is quite logical, because the Physics is a part of science [3-5], in which the science will have a direct impact on the attitudes of the different areas of science, as well as the work that is based on the information available, and the techniques in [3, 6, 7]. Then, [7] claim that almost in all areas of their lives, they are related to the physics of organisms or non-living thing, which extends to the math, biology, and chemistry. According to [5], but the knowledge of physics, the one person who will have to face the difficulties in the study of mathematics. In addition, in the works $[4,8]$. it was said that the understanding of the physics helps to understand the content of the science, and the students develop observation, attention to detail, analytical skills, creative thinking skills, and the knowledge of physics, and it can't be ignored by the students [6].

However, the results of their study of physics is still down on all of the levels in [6]: little in the middle school, [9], or a large high school, [10], as well as the higher education level. [5] the low level of students ' academic performance in physics, which is associated with many factors, such as: the internal and external factors of the students [11, 12]. The intern's elements can be in the attitude, motivation, interest, knowledge, skills, and hopefully, the likely targets [11 to 14] at the same time, an external factor, that is, the state of the students and the learning environment $[11,12]$ how to use the teachers ' teaching method in [2], the family, the environment, and the availability of educational institutions, and infrastructure [13, 14].

One of the main factors that affect the learning outcomes that are of interest to the students the material that is being studied. As mentioned in [12], if a student has a strong interest in studying, learning, performance is usually high. On the contrary, if the interest rate is not the result of the study, it is at a very low level.

Low academic performance of students in physics, and, so far, is because of the physics is to be regarded as a difficult lesson for students, especially if the material is related to the mathematical expectation of the $[3,14]$. On the other hand, the idea of the physics requires an understanding of the mathematical concepts. According to [14], there is a positive correlation between the principle of the math, and the success of the getting the results of a study of the physical sciences. The relationship between the principle of the math, and the results of the study of physics has been described by many researchers. As reported in [10], which is one of the reasons for students ' difficulties in the study of the physics of the weak math skills. In addition, [2] noting that the communications between, to understand the field of mathematics and the ability to solve physical problems, and in [7] indicated that the students with high mathematical abilities to influence the students ' achievement in the study of physics.

The results of the study of the physics of a secondary school students in Dire Dawa, has so far been shown to have the maximum performance. On the other hand, there are no studies in order to find out the students 'interest in physics and/or the students' knowledge of the fundamental concepts in the field of mathematics, and its correlation with the results of the study of physics through high school and college students in Ethiopia. This is due to the fact that the research is still being conducted on the individual researchers in mathematics and physics, without taking into account the importance of the two combinations, rather than according to [12], the ability of physics to students depends on the experience of the students in the study of mathematics. This suggests that the understanding of the physics requires the knowledge of mathematics. In addition, in spite of the fact that, as is well known, and it is not a secret to be of interest, as well as a knowledge of the fundamental concepts in mathematics, in the context of the student's ability to solve the problem, or the result of students not only in physics but also in other areas, however, this type of research has never been carried out in the public education schools, 8, 9, and 10. However, in order to improve the outcomes of students 'learning in 
physics, it is necessary that some of the factors that affect the outcome of students' learning, such as the interest in physics, and a knowledge of the fundamental concepts of mathematics as a source of information for the development of a successful learning experience, the teacher.

All of these studies have made a significant contribution to the literature on teaching; however, we can say that they are all using the selection problem in order to solve the day to day on the oral duties, leaving the room in order to evaluate the data based on the ratio of their knowledge, in order to assess the student's ability to solve the problem in the broader context of the place of work, business, and other purposes. Therefore, in this case, the focus is on the students ' ability to deal with gender-sensitive issues, and the school of the sector, as the light changes. After that, in contrast to the previously described studies, the more severe the statistical analysis using the t-test, the eta-squared and ANOVA.

Methodology:

The study used survey approach of 578 students enrolled in 4 secondary schools sample. Proportionate approach in sampling was adopted as illustrated in the table 1 given below.

Table 1. Composition of the Sample

\begin{tabular}{|l|l|l|l|l|}
\hline & \multicolumn{2}{|l|}{ Sector Wise } & \multicolumn{2}{l|}{ Gender Wise } \\
\hline & Public & Private & Male & Female \\
\hline \%age & 50 & 50 & 70 & 30 \\
\hline Students in sample & 289 & 289 & 405 & 173 \\
\hline
\end{tabular}

Tool: Data was collected thorough a test with six constructed response items. Content validity was ensured through expert opinion and construct validity was check through factor analysis. Reliability of the instrument was found to 0.90 .

\section{Result and Discussion:}

Question based and scale-based performance was analyzed using mean, standard deviation, minimum and maximum to provide an overview of students' performance on each item and on the scale as whole. More item reliability coefficient was also determined. Table 2 below shows the details.

Table 2. Item Statistics for Problem Solving sub scale

\begin{tabular}{|l|l|l|l|l|l|}
\hline Questions & Mean & Std & Min & Max & Alpha dev \\
\hline Question 1 & 2.03 & 1.44 & 0 & 4 & .708 \\
\hline Question 2 & 1.50 & 1.46 & 0 & 4 & .707 \\
\hline Question 3 & 1.58 & 1.49 & 0 & 4 & .692 \\
\hline Question 4 & .94 & 1.35 & 0 & 4 & .682 \\
\hline Question 5 & 1.60 & 1.43 & 0 & 4 & .675 \\
\hline Question 6 & 1.29 & 1.36 & 0 & 4 & .698 \\
\hline Scale & 8.95 & 5.54 & 0 & 24 & .786 \\
\hline
\end{tabular}

Table 2 shows that the mean scores on the Questions about the extent of the problem solving, it is from 0.94 to 2.03, with an overall average of 8.95 for a maximum score of 24 . Question 4 proved to be the most difficult, guided, with an average of 0.94, and to Question 1, it was the easiest thing to do, guided, problem-solving scale, with an average of 2.03. 
Gender comparisons in terms of the question to solve, the results can be used in the form of a test, the t-criteria for assessing the students ' performance in the queue. The Cohen's D value was calculated to refine the mean of the difference. The analysis of this moment, as shown in Table 3 below.

Table 3. gender wise analysis of performance in problem solving

\begin{tabular}{|c|c|c|c|c|c|c|c|}
\hline Scale & $\begin{array}{l}\text { Male } \\
\text { Mear } \\
\text { Dev }\end{array}$ & std. & $\begin{array}{l}\text { Fema } \\
\text { Mear } \\
\text { Dev }\end{array}$ & Std. & t-value & Sig.(2-tailed) & $\begin{array}{l}\text { Effect size } \\
\text { Cohen's d }\end{array}$ \\
\hline Problem Solving & 9.98 & 5.991 & 8.56 & 5.208 & 2.137 & $0.035^{*}$ & 0.253 \\
\hline
\end{tabular}

In Table.3, it can be concluded that there are significant differences between, on the average, men and women, and of men are better than that of their peers. However, the value of $\mathrm{D}$, Cohen (0.25) shows that the impact on the small size.

Table 4 sector wise analysis of performance in problem solving

\begin{tabular}{|c|c|c|c|c|c|c|c|}
\hline Scale & $\begin{array}{l}\text { Publi } \\
\text { Mear }\end{array}$ & d Dev & $\begin{array}{l}\text { Privat } \\
\text { Mean } \\
\text { Dev }\end{array}$ & & t-value & Sig.(2-tailed) & $\begin{array}{l}\text { Effect size } \\
\text { Cohen's d }\end{array}$ \\
\hline Problem So & 6.82 & 4.680 & 11.27 & 5.425 & 8.846 & $0.000 * *$ & 0.87 \\
\hline
\end{tabular}

Table 4 shows that there are significant differences in the average, private, and public-school students, private school students to achieve better results than their peers. However, the value of $\mathrm{D}$, Cohen (0.87) suggests that this effect is of moderate size.

No interaction between the independent variables, such as sector-B, location, and gender, and problem solving, is placed in the multivariate analysis, a possible drug interaction. The results of this analysis are shown in Table 5 below.

Table 5 Interaction between gender and Sector

\begin{tabular}{|l|c|c|}
\hline & $\begin{array}{c}\text { Location \& Sector } \\
\mathrm{Eta}^{2}\end{array}$ & $\begin{array}{c}\text { Sector \& Gender } \\
\mathrm{Eta}^{2}\end{array}$ \\
\hline Problem solving & .000 & .001 \\
\hline
\end{tabular}

Table 5 shows that there is significant interaction effect between the gender and sector on problem solving performance of the students.

\section{Conclusion}

The high score student GROUP, based on mathematical thinking, physics, and the degree of success of the individual, and solving problems, dare to show one of the major advantages of the private sector is most likely due to the better management of the private schools of the teacher.

This is the effect of the interaction between the gender and the sector, in order to solve the problem, it shows that there is a significant impact on the interaction between the gender, and the sector. Most of the private sector, students from well-educated and more affluent families, the administration, and education, and the environment will be different to some degree. The possible causes, in order to improve the performance of students in the private schools can be as 
a result of the improvement of the conditions in the school, because the supply of qualified teachers in the private schools, because the administration of a private school is autonomous, the recruitment of teachers on the basis of their goods and services, as compared to the public sector, with this the greatness of the role of the recruitment and promotion of the services. In addition, private schools, it has to be their teacher, and they will not be satisfied with their work, putting more pressure on the teachers in the school, and they are working hard to be the show's progress. Public schools follow a fixed schedule of time limits established by the Ministry of Education and training, especially during the seasonal holidays, such as private schools, are flexible, and use the maximum of the number of school days in any one calendar year.

Teaching the best practice in teaching, and the evaluation of the diagrams in which, at the most once a month, the tests are a popular tradition, and a report will be sent to the parents. The parents of private school students are getting not only their education, but also to pay for the direct costs in the form of monthly or annual fees, so that they will follow the progress of the students, which not only proves that the motivation of students, but it is also an add-on service for the control of the school board. The culture of competition among private schools, mainly for financial reasons, the school offers the additional benefit of a private-school students, and they have to be given attention in order to get a response at the school, received a high score by collecting the faces of the people.

Gender and the sectors can be combined as independent variables, and solve the problem as the dependent variables, but no interaction was observed. It's the best performance of the female students in the private sector, as compared to the female students of a public school is consistently analysed by T-test, and the differences can be explained by the fact that the supply of teachers, an effective and efficient supervision of the school.

\section{Recommendation}

A higher value of the standard deviation of the physics of thinking, compared with the results of the mathematics show that it is based on the evaluation of the data, with attention to the more effective, than the tests of the elements of the assessment of procedural knowledge, but also to differentiate the students. Therefore, the students ' assessment should include at least some of these issues. This will help you to improve the teachers, in order to better understand the use with your students.

Good interaction between the teacher and the students and between the students, and must be developed through a discussion and solution of complex problems related to their daily lives, in order to promote the development of students ' mathematical thinking and, thus, higher achievement in physics.

Students should not have to have a means in the process of responding to a class of matter and its lack of a mathematical statement, to be used for the learning process. Their weak evidence is not to be rewarded a negative impact.

In this study, a sample, are the tools that are used in the context of the present study can be used by researchers with little or no modification. In this way, in a prospective study, to investigate, and test the generalizability of these studies.

Similar research can be conducted at any level of the students, such as the first and the beginning of the levels. In this case, the researcher needs to look at the model of the mathematical thinking skills, and to develop new tools. 


\section{Reference}

[1].David E. Meltzer, "Relation between students' problem-solving performance and representational format", American Journal of Physics 73, 463-478 (2005) https://doi.org/10.1119/1.1862636

[2]. Javier Pulgar, Valentina Fahler, Alexis Spina. (2021) Investigating how university students collaborate to compose physics problems through structured tasks. Physical Review Physics Education Research 17:1, 010120. Online publication date: 29-Mar2021.

[3]. Nuril Munfaridah, Lucy Avraamidou, Martin Goedhart. (2021) The Use of Multiple Representations in Undergraduate Physics Education: What Do we Know and Where Do we Go from Here?. Eurasia Journal of Mathematics, Science and Technology Education 17:1, em1934.

[4]. B K Prahani, U A Deta, N A Lestari, M Yantidewi, M N RJauhariyah, V P Kelelufna, J Siswanto, M Misbah, S Mahtari, S Suyidno. (2021) A profile of physics multiple representation ability of senior high school students on heat material. Journal of Physics: Conference Series 1760:1, 012020.

[5].M M Chusni, Suranto, S B Rahardjo, S Saputro. (2020) Profile of multi-modal representation ability of junior high school students on science material in Sleman district. Journal of Physics: Conference Series 1511, 012107.

[6]. Gunawan Gunawan, Ahmad Harjono, Lovy Herayanti, Sadam Husein. (2019) ProblemBased Learning Approach with Supported Interactive Multimedia in Physics Course: Its Effects on Critical Thinking Disposition. Journal for the Education of Gifted Young Scientists, 1075-1089.

[7]. M Furqon, Muslim. (2019) Investigating the ability of multiple representations and scientific consistency of high school students on newton's laws. Journal of Physics: Conference Series 1280, 052041.

[8].S E Nugroho, Sunarno, F Setiani. (2019) Students' ability to solve problems in various forms of representation on the topic of direct current electricity. Journal of Physics: Conference Series 1170, 012044.

[9].Ching-Sui Hung, Hsin-Kai Wu. (2018) Tenth graders' problem-solving performance, self-efficacy, and perceptions of physics problems with different representational formats. Physical Review Physics Education Research 14:2, 020114.

[10]. Y Theasy, Wiyanto, Sujarwata. (2018) Multi-representation ability of students on the problem solving physics. Journal of Physics: Conference Series 983, 012005.

[11]. Daisy Kaur, Yi Zhao. (2017) Development of Physics Attitude Scale (PAS): An Instrument to Measure Students' Attitudes Toward Physics. The Asia-Pacific Education Researcher 26:5, 291-304.

[12]. Docktor JL, Dornfeld J, Frodermann E, Heller K, Hsu L, Jackson KA and Yang J 2016 Assessing student written problem solutions: A problem-solving rubric with application to introductory physics Physical Review Physics Education Research 12 10130 
[13]. Selçuk GS, Çal S and Erol M 2008 The Effects of Problem-Solving Instruction on Physics Achievement, Problem Solving Performance, and Strategy Use Journal Physics Education 2 151-166

[14]. Shih YL and Singh C 2013 Using an isomorphic problem pair to learn introductory physics: Transferring from a two-step problem to a three-step problem Physical Review Special Topics-Physics Education Research 9

[15]. Mustefa JIBRIL. A Study of Emotional Intelligence of Electrical Engineering students in Dire Dawa

[16]. University Ethiopia. Rep Opinion 2021;13(7):5-7]. ISSN 1553-9873 (print); ISSN 2375-7205 (online). http://www.sciencepub.net/report. 2. doi:10.7537/marsroj130721.02.

[17]. Mustefa JIBRIL.” Evaluation on Study Skills and Academic Stress on University Engineering Student' s Academic Achievement” ACE Journal of Humanities, Social Sciences and Education, ISSN: 2520 - 3827, Volume 1, Number 2, Page No. 18 - 23, 2021

[18]. Mustefa JIBRIL.” Evaluation on Success of Graduating with Distinction in Higher Education using Fuzzy DEMATEL Method" ACE International Journal of Social Sciences, ISSN: 2520 - 3177, Volume 1, Number 1, Page No. 1 - 5, 2021 [19]. Mustefa JIBRIL.” The Attitude of Students Concerning Gender and Rural Urban Dichotomy in Dire Dawa University" ACE International Journal of Social Sciences, ISSN: 2520 - 3177, Volume 1, Number 3, Page No. 28 - 34, 2021

[20]. Mustefa JIBRIL. The Attitude of Students Towards Learning English Language at Secondary Schools in Dire Dawa Ethiopia. Academia Arena 2021;13(7):61-64]. ISSN 1553-992X (print); ISSN 2158-771X (online), http://www.sciencepub.net/academia. 4. doi:10.7537/marsaaj130721.04.

[21]. Mustefa JIBRIL.” The Evaluation Between Importance of Educational Needs and Satisfaction about it as Perceived by Engineering Students at Dire Dawa University Ethiopia” ACE International Journal of Social Sciences, ISSN: 2520 - 3177, Volume 1, Number 2, Page No. 19 - 24, 2021

[22]. Mustefa JIBRIL The Impact of adjustment on Academic achievement among University Students in Dire Dawa Ethiopia. N Y Sci J 2021;14(7):17-20]. ISSN 15540200 (print); ISSN 2375-723X (online). http://www.sciencepub.net/newyork. 3. doi:10.7537/marsnys140721.03.

[23]. Mustefa JIBRIL.” The Impact of Gender on Adjustment Level of Dire Dawa University Lecturers” ACE International Journal of Social Sciences, ISSN: 2520 3177, Volume 1, Number 2, Page No. 13 - 15, 2021 